\title{
Phosphorus Fractionation Study in Soils of Agricultural Botany Research Farm, Nagpur, India
}

\author{
Monika S. Bhavsar*, Rajanikant B. Ghagare, Sugandh N. Shinde \\ and Rupali B. Ghogare
}

College of Agriculture, Nagpur, Maharashtra, India

*Corresponding author

\begin{abstract}
A B S T R A C T
Keywords

P fractions, Soil properties

Article Info

Accepted:

10 December 2017

Available Online:

10 January 2018

Phosphorus fractionation study in soils of Agricultural Botany Research Farm, Nagpur were studied in which 10 surface $(0-15 \mathrm{~cm}$ depth) and 10 subsurface (15-30 cm depth) soil samples collected from studied area were analysed for different physical and chemical properties and different $\mathrm{P}$ fractions. The content of total $\mathrm{P}$ was very high. Ca-P was the dominant inorganic $\mathrm{P}$ fraction $(41.11 \%)$, followed by Al-P (10.12\%), Reductant soluble P (6.88\%) and Occluded P (4.53\%), Fe-P (4.27\%), Saloid- P $(0.62 \%)$. In general Saloid P, Al-P, Fe-P, R-S-P, Org-P and Total-P showed a decreasing trend with sampling depth while Occld-P, Ca-P showed a increasing trend with increasing depth.
\end{abstract}

\section{Introduction}

Phosphorus is one of the essential nutrient elements and present in to substantial quantities in most of the Indian soils.. Most of Indian soils are reported by (Ghani, 1943) to be rich in total phosphorus content but are poor in their availability. The freshly applied phosphate is utilised by crop plants rest goes into the formation of different $\mathrm{P}$ compound of varying solubility which later serve as potential sources of $\mathrm{P}$ for plants (Kanwar, 1976). Phosphorus, like any other plant nutrient is present in soil in two major components i.e. organic and inorganic.
Organic $\mathrm{P}$, which is mainly confined to the surface layer, is mineralized into inorganic forms but, the plants mainly depend on inorganic $\mathrm{P}$ forms for their $\mathrm{P}$ requirements. Saloid-P, Al-P, Fe-P and Ca-P fractions are the main source of $\mathrm{P}$ supply to the plants. The relative proportion of different forms of inorganic phosphorus depends on various soil characteristics like $\mathrm{pH}$, organic carbon, CaCO3, CEC and texture (Jaggi, 1991). Phosphorus is the backbone of balanced fertilization in Indian agriculture. Information on $\mathrm{P}$ fertility status of soils is of great importance as it helps to determine the level of $\mathrm{P}$ fertilizer to be applied to crops and decide 
on fertilizer distribution and planning at macro and micro levels. The present study was undertaken to assess the status of different forms of phosphorus in given area.

\section{Materials and Methods}

Ten surface and ten subsurface soil samples $(0-15 \mathrm{~cm})$ and $(15-30 \mathrm{~cm})$ depth collected from Agricultural Botany Research Farm, Nagpur were used for the study. The processed soil samples $(<2 \mathrm{~mm})$ were analyzed for $\mathrm{pH}, \mathrm{EC}$, Organic carbon, $\mathrm{CaCO}_{3}, \mathrm{CEC}$, Sand, Silt, Clay and different $\mathrm{P}$ fractions by adopting standard procedures. Total $\mathrm{P}$ in soil was determined using $60 \%$ perchloric acid digestion method as suggested by Piper (1966). The original fractionation procedure for different forms of inorganic $\mathrm{P}$ proposed by Peterson and Corey (1966) and available P by Olsen et al., (1954) were used. Organic $-\mathrm{P}$ was determining as the difference between total $\mathrm{P}$ and total inorganic P.

\section{Results and Discussion}

The relevant physical and chemical characteristics of the soil are present in table 1 and 2 respectively. Majority of the soils of the study area clayey in nature, neutral to moderately alkaline in reaction, Soil organic carbon was moderate to moderately high in soils, EC values for these soils within safe limit, the free lime content indicating that these soils are moderately calcareous in nature. The available phosphorus content of the soils showed low to moderately high in category.

\section{Saloid P}

In Agricultural Botany Research Farms, Nagpur Saloid-P ranged from 2.1 to $3.7 \mathrm{ppm}$ and accounted on an average about 0.62 per cent of the total P. Sharma and Tripathi (1992) reported that, content of Saloid $\mathrm{P}$ on an average 0.8 percent of the total $\mathrm{P}$ and 1.6 per cent of the Inorganic P. In studied area, Saloid $\mathrm{P}$ ranged from 2.3 to $3.7 \mathrm{ppm}$ in surface layer and 2.1 to $3.5 \mathrm{ppm}$ in subsurface layer, it decreased with depth. The higher content of Saloid $\mathrm{P}$ at the surface layer might be due to mixing of $\mathrm{P}$ from fertilizers and manures in the surface soil. Similar results were reported by Viswanath and Doddamani (1991). The highest content of saloid $\mathrm{P}$ was observed 3.7 ppm in BOT-1(1) sample $(0-15 \mathrm{~cm})$ depth and $2.1 \mathrm{ppm}$ in BOT-1(4) sample $(15-30 \mathrm{~cm})$ depth. The variation in saloid $P$ in the studied area soils can be attributed to the variation in clay, organic carbon and available $\mathrm{P}$ content Devra et al., (2014).

\section{Aluminium-P}

The distribution of Al-P decreased with sampling depth. This might be due to increase amount of calcium carbonate in the soil with increasing depth. The results corroborate the finding of Gupta and Cornfield (1962).

The Al-P varied from $40.56 \mathrm{ppm}$ to 53.15 ppm. It contributed about $10.12 \%$ of total-P. The Al-P in surface soil ranged from 47.12 $\mathrm{ppm}$ to $53.15 \mathrm{ppm}$ and sub-surface was ranges from $40.56 \mathrm{ppm}$ to $48.14 \mathrm{ppm}$. The higher concentration of Al-P was recorded in BOT4(15) (53.15 ppm) in $0-15 \mathrm{~cm}$ depth and lowest value was recorded in BOT-2(8) sample (40.56 ppm) in $15-30 \mathrm{~cm}$ depth. The Al-P was higher where inorganic fertilizers were used as a source of phosphorus.

\section{Iron bound phosphorus ( $\mathrm{Fe}-\mathrm{P})$}

The Fe-P content shows variations in all samples. According to table $3 \mathrm{Fe}-\mathrm{P}$ content varies between $14.15 \mathrm{ppm}$ and $28.34 \mathrm{ppm}$. It ranges between $15.70 \mathrm{ppm}$ and $28.34 \mathrm{ppm}$ in surface samples and $14.15 \mathrm{ppm}$ to $25.15 \mathrm{ppm}$ in subsurface samples. The higher Fe-P content was found in BOT-1(1) sample (28.34 
ppm) in $0-15 \mathrm{~cm}$ depth and lowest $\mathrm{Fe}-\mathrm{P}$ was found in BOT-4(16) sample (14.15 ppm) in $15-30 \mathrm{~cm}$ depth. It contributes 4.27 per cent of total P. These results were in accordance with that of Viswanath and Doddamani (1991). Fe$\mathrm{P}$ was found higher in surface soil due to higher organic carbon content, higher amount of calcium carbonate was recorded at higher $\mathrm{pH}$ where iron activity was less to precipitate $\mathrm{P}$ into $\mathrm{Fe}$, Chandra Bhan and Harishankar (1973), Devra et al., (2014).

\section{Calcium-P}

The Ca-P is the fraction of soil phosphorus that can be readily adsorbed by growing plants. However, this was very dominant fraction of total phosphorus and even in the fertile soil this form can supply the major requirements of the crops the data on Ca-P of soils in the studied area has been presented in table 3. The Ca-P varied from $182.09 \mathrm{ppm}$ to $208.45 \mathrm{ppm}$ and accounted about 41.11 per cent of total P. This might be attributed with finding of Mishra and Ojha (1969) and Viswanath and Doddamani (1991). Ca-P was observed in surface layer $182.09 \mathrm{ppm}$ to $201.45 \mathrm{ppm}$ and $190.03 \mathrm{ppm}$ to $208.45 \mathrm{ppm}$ in subsurface layer, Singh (2010). The lowest value $182.09 \mathrm{ppm}$ in $0-15 \mathrm{~cm}$ depth in BOT1(1) and highest value $208.45 \mathrm{ppm}$ was observed in BOT-4(16) in 15-30 cm depth. Ca-p was increased with increasing depth similar result was obtained by Trivedi (2010). The results showed Ca-P in calcareous soil was reported by Kathandaraman and Krishnamoorthy (1979) in black soil of Tamilnadu, while its dominances in alkaline soils was reported by Shrivastava and Pathak (1970) and its dominances also observed in Westerner plain of Rajasthan soil by Devra $e t$ al., (2014).

Table.1 Physical properties of soils in Agricultural Botany Research Farm, Nagpur

\begin{tabular}{|c|c|c|c|c|c|c|}
\hline \multirow{2}{*}{ Sr. no } & Depth $(\mathbf{c m})$ & \multicolumn{2}{|c|}{ Particle size distribution (per cent) } & $\begin{array}{c}\text { Textural } \\
\text { class }\end{array}$ \\
\hline & & Sand \% & Silt \% & Clay \% & Clayey \\
\hline BOT-1(1) & $0-15$ & 18.5 & 19.8 & 56.90 & Clayey \\
\hline BOT-1(2) & $15-30$ & 20.5 & 20.86 & 53.75 & Clayey \\
\hline BOT-1(3) & $0-15$ & 19.53 & 24.20 & 56.27 & Clayey \\
\hline BOT-1(4) & $15-30$ & 21.37 & 25.33 & 52.20 & Clayey \\
\hline BOT-2(5) & $0-15$ & 16.5 & 22.10 & 58.56 & Clayey \\
\hline BOT-2(6) & $15-30$ & 18.1 & 23.70 & 55.00 & Clayey \\
\hline BOT-2(7) & $0-15$ & 19.50 & 23.50 & 56.32 & Clayey \\
\hline BOT-2(8) & $15-30$ & 21.80 & 21.20 & 53.20 & Clayey \\
\hline BOT-3(9) & $0-15$ & 20.22 & 21.53 & 58.25 & Clayey \\
\hline BOT-3(10) & $15-30$ & 21.1 & 20.5 & 55.03 & Clayey \\
\hline BOT-3(11) & $0-15$ & 17.20 & 21.6 & 58.88 & Clayey \\
\hline BOT-3(12) & $15-30$ & 19.60 & 22.3 & 56.20 & Clayey \\
\hline BOT-4(13) & $0-15$ & 18.81 & 22.40 & 58.80 & Clayey \\
\hline BOT-4(14) & $15-30$ & 20.95 & 20.55 & 56.3 & Clayey \\
\hline BOT-4(15) & $0-15$ & 20.70 & 22.50 & 56.71 & Clayey \\
\hline BOT-4(16) & $15-30$ & 21.30 & 25.20 & 52.60 & Clayey \\
\hline BOT-5(17) & $0-15$ & 18.96 & 21.07 & 58.24 & Clayey \\
\hline BOT-5(18) & $15-30$ & 19.51 & 22.46 & 55.09 & Clayey \\
\hline BOT-5(19) & $0-15$ & 20.87 & 22.75 & 55.30 & Clayey \\
\hline BOT-5(20) & $0-15$ & 22.59 & 24.17 & 53.24 & \\
\hline & & & & & \\
\hline
\end{tabular}


Table.2 Chemical properties of soils in Agricultural Botany Farm, Nagpur

\begin{tabular}{|c|c|c|c|c|c|c|}
\hline Sr. no & $\begin{array}{l}\text { Depth } \\
\text { (cm) }\end{array}$ & $\underset{(1: 2.5)}{\mathrm{pH}}$ & $\begin{array}{c}\mathrm{EC} \\
\mathrm{dSm}^{-1}\end{array}$ & $\begin{array}{c}\text { Organic } \\
\text { Carbon (\%) }\end{array}$ & $\begin{array}{c}\mathrm{CaCO}_{3} \\
(\%)\end{array}$ & $\begin{array}{c}\text { Available } \\
\text { Phosphorus (kg ha } \\
{ }^{1} \text { ) }\end{array}$ \\
\hline BOT-1(1) & $0-15$ & 7.3 & 0.24 & 0.71 & 4.52 & 15.21 \\
\hline BOT-1(2) & $15-30$ & 7.5 & 0.25 & 0.67 & 4.91 & 12.30 \\
\hline BOT-1(3) & $0-15$ & 7.6 & 0.31 & 0.79 & 4.70 & 16.25 \\
\hline BOT-1(4) & $15-30$ & 7.9 & 0.38 & 0.71 & 5.12 & 14.01 \\
\hline BOT-2(5) & $0-15$ & 7.7 & 0.40 & 0.58 & 3.68 & 16.60 \\
\hline BOT-2(6) & $15-30$ & 7.9 & 0.42 & 0.52 & 4.75 & 13.15 \\
\hline BOT-2(7) & $0-15$ & 7.4 & 0.26 & 0.65 & 4.50 & 18.17 \\
\hline BOT-2(8) & $15-30$ & 7.8 & 0.31 & 0.60 & 5.61 & 15.10 \\
\hline BOT-3(9) & $0-15$ & 7.8 & 0.33 & 0.73 & 4.56 & 14.11 \\
\hline BOT-3(10) & $15-30$ & 8.0 & 0.39 & 0.68 & 5.14 & 12.15 \\
\hline BOT-3(11) & $0-15$ & 7.5 & 0.36 & 0.68 & 4.96 & 17.20 \\
\hline BOT-3(12) & $15-30$ & 8.0 & 0.38 & 0.61 & 5.39 & 14.35 \\
\hline BOT-4(13) & $0-15$ & 7.7 & 0.35 & 0.78 & 4.61 & 13.18 \\
\hline BOT-4(14) & $15-30$ & 8.1 & 0.40 & 0.72 & 5.25 & 11.23 \\
\hline BOT-4(15) & $0-15$ & 7.4 & 0.30 & 0.54 & 4.57 & 16.33 \\
\hline BOT-4(16) & $15-30$ & 7.6 & 0.34 & 0.47 & 5.48 & 14.18 \\
\hline BOT-5(17) & $0-15$ & 7.7 & 0.35 & 0.68 & 3.87 & 17.21 \\
\hline BOT-5(18) & $15-30$ & 7.8 & 0.37 & 0.62 & 4.76 & 15.36 \\
\hline BOT-5(19) & $0-15$ & 7.4 & 0.36 & 0.65 & 4.45 & 18.30 \\
\hline BOT-5(20) & $15-30$ & 7.6 & 0.39 & 0.58 & 4.80 & 16.19 \\
\hline
\end{tabular}

Table.3 Distribution of soil phosphorus form (ppm) in Agricultural Botany Research Farm, Nagpur

\begin{tabular}{|l|c|c|c|c|c|c|c|c|c|c|}
\hline Sr.no & $\begin{array}{c}\text { Depth } \\
\text { cm }\end{array}$ & S- P & Al- P & Fe- P & Ca-P & Red-P & Occl-P & Inorg-p & Org-P & Total-P \\
\hline BOT-1(1) & $0-15$ & 3.7 & 48.38 & 28.34 & 182.09 & 39.13 & 18.34 & 319.98 & 170.6 & 490.58 \\
\hline BOT-1(2) & $15-30$ & 2.8 & 41.18 & 25.15 & 190.03 & 36.09 & 21.45 & 316.7 & 116.74 & 433.44 \\
\hline BOT-1(3) & $0-15$ & 2.6 & 47.12 & 19.34 & 194.34 & 32.67 & 14.88 & 310.95 & 184.25 & 495.20 \\
\hline BOT-1(4) & $15-30$ & 2.1 & 42.15 & 15.75 & 203.48 & 27.45 & 17.13 & 308.06 & 132.3 & 440.36 \\
\hline BOT-2(5) & $0-15$ & 3.4 & 50.14 & 15.70 & 196.14 & 30.15 & 15.98 & 311.51 & 159.28 & 480.79 \\
\hline BOT-2(6) & $15-30$ & 2.5 & 42.24 & 14.53 & 201.41 & 23.99 & 19.12 & 303.82 & 89.34 & 393.16 \\
\hline BOT-2(7) & $0-15$ & 3.0 & 47.20 & 20.12 & 198.88 & 33.56 & 21.45 & 324.21 & 174.02 & 498.23 \\
\hline BOT-2(8) & $15-30$ & 2.9 & 40.56 & 16.32 & 202.47 & 28.70 & 25.23 & 316.18 & 140.49 & 456.67 \\
\hline BOT-3(9) & $0-15$ & 3.1 & 48.84 & 24.36 & 193.2 & 31.45 & 18.45 & 319.4 & 162.87 & 482.27 \\
\hline BOT-3(10) & $15-30$ & 3.5 & 43.26 & 21.75 & 200.42 & 26.75 & 21.70 & 317.38 & 141.79 & 459.17 \\
\hline BOT-3(1) & $0-15$ & 3.6 & 50.55 & 23.70 & 199.34 & 39.10 & 22.2 & 338.59 & 173.44 & 512.03 \\
\hline BOT-3(12) & $15-30$ & 2.8 & 43.12 & 19.34 & 207.98 & 35.10 & 20.34 & 328.68 & 127.77 & 456.45 \\
\hline BOT-4(13) & $0-15$ & 3.2 & 51.15 & 19.95 & 196.34 & 32.16 & 18.34 & 321.14 & 170.59 & 491.73 \\
\hline \hline BOT-4(14) & $15-30$ & 3.0 & 48.14 & 15.70 & 206.44 & 30.17 & 21.66 & 325.11 & 128.91 & 454.02 \\
\hline BOT-4(15) & $0-15$ & 2.5 & 53.15 & 20.18 & 201.25 & 30.45 & 22.45 & 329.98 & 143.55 & 473.53 \\
\hline BOT-4(16) & $15-30$ & 2.2 & 46.67 & 14.15 & 208.45 & 26.47 & 25.3 & 319.24 & 93.22 & 412.46 \\
\hline BOT-5(17) & $0-15$ & 3.0 & 52.14 & 22.18 & 195.89 & 35.18 & 21.52 & 328.91 & 129.37 & 458.28 \\
\hline BOT-5(18) & $15-30$ & 2.7 & 45.32 & 16.17 & 203.87 & 32.12 & 23.5 & 323.68 & 96.68 & 420.36 \\
\hline BOT-5(19) & $0-15$ & 2.8 & 47.12 & 24.36 & 201.45 & 33.06 & 20.86 & 327.15 & 140.29 & 467.44 \\
\hline BOT-5(20) & $15-30$ & 2.3 & 42.56 & 21.12 & 207.13 & 29.45 & 24.35 & 327.41 & 83.21 & 410.62 \\
\hline
\end{tabular}




\section{Reductant-P}

The Reductant $-\mathrm{P}$ varied from 23.99. ppm to $39.13 \mathrm{ppm}$. It accounted about 6.88 per cent of the total-P. The highest value was observed in BOT-1(1) sample (39.13 ppm) in 0-15 cm depth and lowest value was observed in BOT-2(6) sample (23.99 ppm) in 15-30 cm depth. In surface it was ranges from $30.15 \mathrm{ppm}$ to 39.13 ppm and in subsurface ranges from 23.99 ppm $36.09 \mathrm{ppm}$.

\section{Occluded-P}

The Occluded $-\mathrm{P}$ ranged from $14.88 \mathrm{ppm}$ to $25.30 \mathrm{ppm}$. It accounted about 4.53 per cent of total-P. The highest value of Occl $-\mathrm{P}$ was observed in BOT-4(16) sample (25.30 ppm) in $15-30 \mathrm{~cm}$ depth and lowest value was observed in BOT-1(3) sample (14.88 ppm) in $0-15 \mathrm{~cm}$ depth. Similar the results were found by Singh and Omankar (1987). The Khan and Mamdal (1973) reported that in calcareous soil the inorganic $\mathrm{P}$ forms were in order of Ca-P, Occl$\mathrm{P}, \mathrm{Fe}-\mathrm{P}, \mathrm{Al}-\mathrm{P}$.

\section{Organic-P}

The organic $\mathrm{P}$ was mainly located in fulvic acid fractions. The soils having high organic matter content generally have high Organic -P. Org-P content in the soils decreased with depth. The Org-P content in the soil varied from $83.21 \mathrm{ppm}$ to $184.25 \mathrm{ppm}$ which contributed about 28.58 per cent of the total-P. Khan and Mandal (1973) reported that, the Org-P constituted 29.82 per cent of the total P. Similar trend was also reported by Kothandarman and Krishnamoorthy (1978).

The highest value observed in BOT-1(3) sample (184.25 ppm) in 0-15 cm depth and lowest value was observed in BOT-5(20) sample (83.21 ppm) in $15-30 \mathrm{~cm}$ depth. In surface layer it was ranges from $129.37 \mathrm{ppm}-184.25 \mathrm{ppm}$ and in subsurface layer $83.21 \mathrm{ppm}-141.79 \mathrm{ppm}$.In generally Org-P and its per cent to total $\mathrm{P}$ was found to decrease with depth. The decrease of organic phosphorus in soil may be attributed to the decreased of organic matter and organic carbon with depth. Similar trends were recorded by the Kothandaraman and Krishnammorthy (1977), Viswanath and Doddamani (1991). Since all soils were calcareous in nature, organic phosphorus was relatively low.

\section{Total-P}

The Total $\mathrm{P}$ content indicates the reserves of this element in the soil. The total $\mathrm{P}$ content in the soils of Agricultural Botany Research Farm, Nagpur varied from $393.16 \mathrm{ppm}$ to $512.03 \mathrm{ppm}$. The range was quite large which might be due to variation in crop management practices. The total $\mathrm{P}$ content in the soils was generally higher in the surface layer than in subsurface layer and decreased with depth.

The decreased in total-P content may be due to decrease in organic matter content down to depth of soil. Similar result, also reported by Viswanath and Doddamani (1991) and Dongale (1993). The highest content of total P in surface layers may be attributed to continuous addition of manure and fertilizer in this layer. The highest value of Total-P were observed 513.03 ppm in BOT-3(11) $(0-15 \mathrm{~cm})$ and lowest value observed $393.16 \mathrm{ppm}$ in BOT-2(6) in (15-30 $\mathrm{cm})$. In surface layer it was ranges from 467.44 ppm to $512.03 \mathrm{ppm}$ and in subsurface layer it was ranges from $393.16 \mathrm{ppm}$ to $459.17 \mathrm{ppm}$.

The higher range of total $\mathrm{P}$ might be due to the soil derived from basal and basic igneous parent material. Similar observation was reported by Williams and Steinbergs (1958). They reported that soil derived from basalt and basic igneous parent material contained higher amount of phosphorus than those derived from granite.

\section{References}

Bhan and Harishankar, 1973. Study on forms and contents of soil phosphorus and their interrelationship with some physicochemical characteristics of selected soils of Uttar Pradesh. J. Indian Soci. Soil Sci. 21, 177-180. 
Devra, P., S. R. Yadav and I. J. Gulati, 2014. Distribution of different phosphorus fractions and their relationship with soil properties in western plain of Rajasthan. Agropedology, 24(1): 20-28.

Dongale, J. H., 1993. Depthwise distribution of different forms of phosphorus in lateritic soils of coastal region. J. Indian Soc. Soil Sci, 41(1): 62-66.

Ghani, M.C and S. A. Aleem, 1943. Studied on the different forms of phosphorus in some Indian soils. I. surface distribution. Indian J. Agri.soci. 13(3): 283-288.

Gupta, M. B. S. and A. H. Cornfield, 1962. Dynamics of phosphorus. Leading paper presented by $\mathrm{N}$. K. Tomar at $65^{\text {th }}$ annual convention of Indian Society of Soil Science seminar, at NBSS and LUP Nagpur.

Jaggi, R. C., 1991. Inorganic phosphate fractions as related to soil properties in some Representative soils of Himachal Pradesh. J. Indian Soc. Soil Sci. 39: 567-568.

Kanwar, J. S. 1976. Soil fertility theory and practice (Indian Council of Agricultural Research, New Delhi).

Khan and Mandal, 1973. The distribution of different inorganic forms of phosphorus in rice soils of West Bengal. J. Indian Soc. Soil Sci. 21(4):395-402.

Kothandaraman, G. V. and K. K. Krishanamoorthy, 1977. Diaribution of inorganic phosphorus fractions in Tamil Nadu soil. Madras Agricultural J. 64: 516521.

Mishra, M. L. and S. K. Ojha, 1969.Release of retained phosphorus by various extractants. J. Indian Soc Soil Sci. 17(1): 67-74.

Olsen, S. R., Cole, C. V., Watanabe, F.S. and Dean, L.A. 1954. Estimation of available phosphorus in soils by extraction with sodium bicarbonate U.S. D.A circular 939.

Peterson, G.W. and R.B. Corey, 1966. Modified Chang and Jackson procedure for routine fractionation of Inorganic soil phosphate. Pro. Soil Sci. Amer. 30:563.

Piper, C.S., 1966. Soil and plant analysis iv edition. University of Acelcide Adeitada, Australia. 135-200.

Sharma, P.K. and B. R. Tripathi, 1992. Fractions of phosphorus from some acid hill soils of North-West India. J. Indian Soc. Soil Sci., 40:59-65.

Shrivastava, O. P. and A. N. Pathak, 1970. Effect of texture on the availability of soil phosphorus. Phosphorsaure. 28:181-187.

Singh R. P., Balwinder and N. S. Dhillon, 2010. Effect of long term differential fertilization on distribution of inorganic-P fractions and $P$ nutrition of wheat under maize-wheat sequence. Indian Soc. of Soil Sci. 58(2): 234-237.

Singh, R and P. K. Omankar, 1987. Phosphorus forms in some soil of mid-western Uttar Pradesh. Profile distribution and transformation of phosphorus. J. Indian Soc. Soil Sci., 35 (4): 634-641.

Trivedi S. K., R. A. S. Tomar, P. S. Tomar and Naresh Gupta. 2010. Vertical distribution of different forms of phosphorus in Alluvial soils of Gird Region of Madhya Pradesh. J. Indian soc. Soil sci. Vol. 58(1): 86-90.

Vishwanath, J. and V. S. Doddamani.1991. Distribution of $\mathrm{P}$ fractions in some Vertisols. J. Indian Soc. Soil Sci. 39:441445.

Williams, C. H. and Steinbergs.1958. Dynamics of phosphorus. Leading paper presented by N. K. Tomar at $65^{\text {th }}$ annual convention of Indian Society of Soil Science seminar, at NBSS and LUP Nagpur.

\section{How to cite this article:}

Monika S. Bhavsar, Rajanikant B. Ghagare, Sugandh N. Shinde and Rupali B. Ghogare. 2018. Phosphorus Fractionation Study in Soils of Agricultural Botany Research Farm, Nagpur, India. Int.J.Curr.Microbiol.App.Sci. 7(01): 1124-1129. doi: https://doi.org/10.20546/ijcmas.2018.701.136 